\title{
Permeable Pavements as a Means to Save Water in Buildings: State of the Art in Brazil
}

\author{
Igor Catão Martins Vaz (D), Lucas Niehuns Antunes (D), Enedir Ghisi *(D) and Liseane Padilha Thives (DD \\ Department of Civil Engineering, Federal University of Santa Catarina, Florianópolis 88040-900, Brazil; \\ igor.catao@posgrad.ufsc.br (I.C.M.V.); lniehuns@hawk.iit.edu (L.N.A.); liseanethives@gmail.com (L.P.T.) \\ * Correspondence: enedir.ghisi@ufsc.br
}

Citation: Martins Vaz, I.C.; Antunes, L.N.; Ghisi, E.; Thives, L.P. Permeable Pavements as a Means to Save Water in Buildings: State of the Art in Brazil. Sci 2021, 3, 36. https://doi.org/ $10.3390 /$ sci3040036

Academic Editor: Giuseppe Cantisani

Received: 25 August 2021

Accepted: 6 October 2021

Published: 14 October 2021

Publisher's Note: MDPI stays neutral with regard to jurisdictional claims in published maps and institutional affiliations.

Copyright: (c) 2021 by the authors. Licensee MDPI, Basel, Switzerland. This article is an open access article distributed under the terms and conditions of the Creative Commons Attribution (CC BY) license (https:// creativecommons.org/licenses/by/ $4.0 /)$.

\begin{abstract}
Permeable pavements have been the subject of numerous studies in recent decades. The possibility of dissipating stormwater more smoothly and generating numerous benefits to the environment and users makes the use of permeable pavements an excellent possibility of integration into sustainable and resilient water management systems in cities. In Brazil, numerous studies on the quantity and quality of infiltrated water, permeability of the coating, clogging, environmental burden, and feasibility, among other characteristics, have been researched. Within this theme, the Federal University of Santa Catarina (UFSC) has contributed with ten papers in the research of permeable pavements in the last six years, which address various topics about the effectiveness and applicability of permeable pavements. This paper reviews the studies conducted at UFSC on permeable pavements and discusses the different results within the main issues found. In general, the selected documents addressed seven themes in the studies: potential for potable water savings, clogging, quantity and quality of the water infiltrated into the pavement, Life Cycle Assessment (LCA) and its variants, and hydraulic and structural design details. More specifically, many selected papers assess the potential use of stormwater harvested through permeable pavements in non-potable uses of buildings. The possibility of aligning the benefits of green infrastructure with the rational use of water expands the advantages of the system and can help prevent future water scarcity, as well as reduce the environmental impacts of paving.
\end{abstract}

Keywords: permeable pavements; potable water savings; life cycle assessment; sustainable urban drainage systems; stormwater harvesting

\section{Introduction}

One of the greatest difficulties of urban centres is to reconcile the population growth with the existing water infrastructures to meet future scenarios. Population increase is a growing trend in Brazilian and world cities [1], from which the increase in building and built environment densification results in soil sealing and consequent increase in the volume of demanded water. In addition, local infrastructures are not always prepared to these changes in the urban drainage conditions [2,3]. In this scenario, undesirable side effects occur, such as the inefficiency of urban drainage systems and the increase in the number of days with the interruption of water distribution.

With the growing demand and the difficulties in water harvesting and treatment, water scarcity in cities is a cause for concern, especially with the advances of climate change [4]. São Paulo, Cape Town and Thirukkovil are examples of cities where recent droughts have culminated in high water scarcity and water rationing [5-7]. Another important topic is climate change and increased peak rainfall intensity, which directly impacts urban drainage efficiency [8]. Higher intensity precipitations generate an increase in surface runoff and the consequent overload of drainage devices. Thus, the option for systems that complement each other is necessary to meet the current hydraulic demands and rainfall intensities, be resilient and meet future variables that interfere in the drainage and supply systems [9]. 
The current urban drainage systems, which use galleries and pipes, are characterised by the fast runoff flow towards disposal. Therefore, the system is defined by design processes with historical data, which presents physical limitations on the number of devices and the diameter of the chosen pipes. With the constant increase of soil sealing, the drainage system is subject to overload, from which climate change and population increase contribute to worsening the problem [10]. Recently, numerous cases of ineffective drainage have been observed in Brazil, resulting in the accumulation of water puddles and flooding. As a result, the streets become hampered and even proliferate diffuse pollution in the pavement coating [11]. The development of projects with resilient drainage systems and slower water dissipation is essential, as it can help restore the natural water cycle and promote an increase of permeable surfaces. In this context, permeable pavements thrive [12].

Permeable pavements are widely disseminated in academic and practical environments, with numerous research on environmental impacts, benefits, quality of infiltrated water, improvements in drainage, structural capacity, among other aspects [13]. There are several practical examples of permeable pavements in the literature within parking lots, light traffic roads and sidewalks. This technology makes it possible to reduce impacts generated by disorderly urbanisation and minimise existing problems in the current models of urban drainages, such as inefficiency due to water overload and the local accumulation of pollutants [14].

Recent studies focus on the development of permeable pavement projects through the correct selection of the materials of each layer of the pavement to obtain better performance regarding the mechanical capacity, the quality of the infiltrated water and the clogging, and to increase the service life [15]. Many authors assert that permeable pavements may answer the problems of current drainage systems and reduce the amount of water runoff and pollution in contact with users. Due to better tyre-pavement adhesion, permeable asphalt mixtures also reduce the risk of skidding, hydroplaning and contribute to the reduction of noise caused by passing vehicles $[16,17]$. These characteristics are advantageous for reducing the risk of accidents on rainy days and beneficial for roads around educational centres.

One of the main benefits provided by permeable pavements is the control of pollution at the source. The quality of runoff on roads is compromised by atmospheric effects and diffuse pollution, which leads to the transposition of pollutants through the drainage. On the other hand, when runoff water infiltrates into the drainage layers of the permeable pavement, these serve as an initial filter, with the capacity to retain unwanted compounds. Several studies in the literature have evaluated runoff water and have proven the reduction of components, for example, heavy metals [18-27], oils, greases or hydrocarbons [20,23,28], Escherichia coli [24-26,29,30], compounds with nitrogen or total nitrogen [21-25,27,31-35] and compounds with phosphorus or total phosphorus [21-27,31,33-35]. Other studies also assessed pH [21,23,31,33,35,36], turbidity [21,31,36], Chemical Oxygen Demand (COD) [24,27], Biochemical Oxygen Demand (BOD) [30,31], electrical conductivity [20,21,23,31,36], hardness [20] and suspended solids [21-27,30,31,33,34].

Considering the benefits and advantages of permeable pavements, it is still necessary to compare the various drainage models to optimise the appropriate system. One of the most applied methodologies is the Life Cycle Assessment (LCA) and its variants of cost, Life Cycle Cost Assessment (LCCA), and energy, Life Cycle Energy Assessment (LCEA). Some studies have evaluated the LCA [37-40], energy-related analysis [39,41] and LCCA $[39,40,42,43]$ of concrete or asphalt permeable pavement systems or coatings. Antunes et al. [44], for example, conducted a systematic review of the LCA of permeable pavements, whose conclusions corroborate the need for maturation of the technique. The authors also comment on the feasibility obtained in the studies evaluated and environmental benefits in contrast to the usual models of urban drainage. 
Research on systems that use permeable pavements to harvest rainwater for use in buildings has also been successful. By combining both techniques, a greater area of rainwater can be provided to achieve a greater volume of rainwater than roof harvesting systems. The potential for potable water savings of more than $80 \%$ can be achieved, depending on the catchment area, the volume of the lower reservoir and the end uses of the building. The current state of the art of permeable pavements shows the potential for different possibilities of integration and relief in the current drainage system. Numerous studies have proven benefits in using permeable pavements and evaluated sustainability and feasibility through systematised comparative analyses. This paper aims to present and group the research on permeable pavements developed at the Federal University of Santa Catarina (UFSC) and contribute to the current state of the art.

\section{Materials and Methods}

This research performed a literature review of technical-scientific papers published by UFSC related to permeable pavements. The main aspects considered in the analysis deal with rainwater harvesting through urban pavements, quantitative and qualitative analysis of stormwater, clogging, LCA, LCEA, LCCA, hydraulic and structural design characteristics. Ten articles were selected in a time span of six years, between 2016 and 2021. Figure 1 shows the main topics found in the literature review and in the evaluated articles, which served as a basis for evaluating the selected articles.

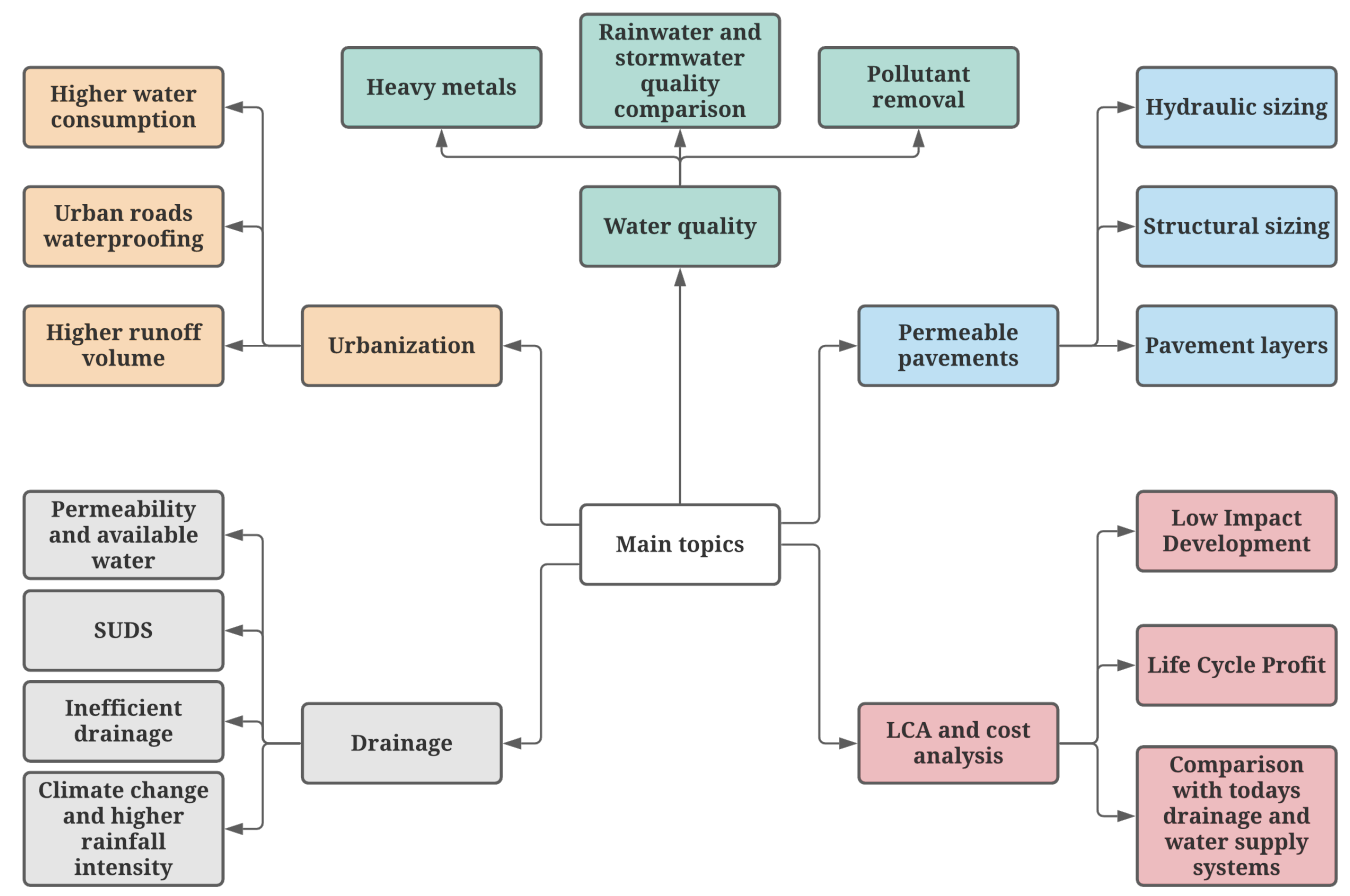

Figure 1. Permeable pavements and rainwater harvesting main research topics.

\subsection{Papers Analysed}

Table 1 presents the selected articles. The selection criteria were defined through previous analysis of the abstracts, i.e., one chose the papers focusing on rainwater harvesting through permeable or impermeable pavements for use in buildings.

From the selection criteria, six main themes were chosen (Table 2): potential for potable water savings, clogging, quantity of infiltrated water in the models, quality of infiltrated water in the models, LCA, LCEA and LCCA of the harvesting systems, hydraulic design of the model and structural design of the model. The potential for potable water savings deals with the evaluation of rainwater harvesting systems through permeable pavements via computer simulations, while clogging refers to the studies of coating durability and void fillings. Quantitative analysis addresses the volume of infiltrated water in the permeable 
pavement systems; quality parameters of the infiltrated water are measured and compared with potability standards. LCA, LCEA and LCCA refer to studies that perform Life Cycle Assessment or its variants; hydraulic design refers to the definition of thickness of pavement layers to meet the hydraulic aspect, and structural design refers to the definition of thickness of pavement layers to meet the demands of vehicular traffic.

Table 1. List of selected papers.

\begin{tabular}{|c|c|c|c|}
\hline ID & Authors & Year & Title \\
\hline 1 & Antunes et al. [45] & 2016 & $\begin{array}{l}\text { Potential for potable water savings in buildings by using stormwater harvested } \\
\text { from porous pavements }\end{array}$ \\
\hline 2 & Antunes et al. [46] & $2020 a$ & $\begin{array}{l}\text { Environmental assessment of a permeable pavement system used to harvest } \\
\text { stormwater for non-potable water uses in a building }\end{array}$ \\
\hline 3 & Antunes et al. [47] & $2020 b$ & $\begin{array}{l}\text { Reduction of environmental impacts due to using permeable pavements to } \\
\text { harvest stormwater }\end{array}$ \\
\hline 4 & Garcia et al. [48] & 2019 & $\begin{array}{l}\text { Analysis of permeability reduction in drainage asphalt mixtures due to decrease in } \\
\text { void volume }\end{array}$ \\
\hline 5 & Ghisi et al. [49] & 2020 & $\begin{array}{l}\text { The use of permeable interlocking concrete pavement to filter stormwater for } \\
\text { non-potable uses in buildings }\end{array}$ \\
\hline 6 & Hammes et al. [50] & 2018 & $\begin{array}{l}\text { Application of stormwater collected from porous asphalt pavements for } \\
\text { non-potable uses in buildings }\end{array}$ \\
\hline 7 & Martins Vaz et al. [51] & 2020 & $\begin{array}{l}\text { Life cycle energy assessment and economic feasibility of stormwater harvested } \\
\text { from pervious pavements }\end{array}$ \\
\hline 8 & Martins Vaz et al. [52] & 2021 & $\begin{array}{l}\text { Stormwater harvested from permeable pavements as a means to save potable } \\
\text { water in buildings }\end{array}$ \\
\hline 9 & Thives et al. [53] & $2018 \mathrm{a}$ & Filtering capability of porous asphalt pavements \\
\hline 10 & Thives et al. [54] & $2018 b$ & $\begin{array}{l}\text { Potable water savings in multifamily buildings using stormwater runoff from } \\
\text { impermeable paved streets }\end{array}$ \\
\hline
\end{tabular}

Table 2. Subjects addressed in each paper.

\begin{tabular}{|c|c|c|c|c|c|c|c|}
\hline Study & $\begin{array}{c}\text { Potable Water } \\
\text { Savings Potential }\end{array}$ & Clogging & Quantity & Quality & $\begin{array}{c}\text { LCA LCEA or } \\
\text { LCCA }\end{array}$ & $\begin{array}{l}\text { Hydraulic } \\
\text { Design }\end{array}$ & $\begin{array}{l}\text { Structural } \\
\text { Design }\end{array}$ \\
\hline Antunes et al. [45] & $x$ & - & $x$ & $x$ & - & - & - \\
\hline Antunes et al. [46] & $X$ & - & - & - & $X$ & $X$ & - \\
\hline Antunes et al. [47] & $x$ & - & - & - & $x$ & $x$ & - \\
\hline Garcia et al. [48] & - & $X$ & - & - & - & - & - \\
\hline Ghisi et al. [49] & - & - & $x$ & $x$ & - & - & - \\
\hline Hammes et al. [50] & $x$ & - & $x$ & $x$ & - & $x$ & - \\
\hline Martins Vaz et al. [51] & $x$ & - & - & - & $x$ & $x$ & - \\
\hline Martins Vaz et al. [52] & $x$ & - & - & - & - & $x$ & $x$ \\
\hline Thives et al. [53] & - & - & $X$ & $x$ & - & - & - \\
\hline Thives et al. [54] & $x$ & - & - & - & - & - & - \\
\hline
\end{tabular}

\subsection{Stormwater Harvesting}

The potential for potable water savings is the focus of part of the selected articles and refers to the percentage of a building's total water demand, potable and non-potable that can be supplied by harvested rainwater. Harvested water can be used for non-potable purposes, such as toilet flushing, irrigation and pavement washing, among other uses. The quality parameters for non-potable uses are defined by the Brazilian standard NBR 
16783 [55]. Equation (1) shows the calculation of the potential for potable water savings by Netuno 4 [56]:

$$
E_{\text {pot }}=100 * \frac{\sum_{i=1}^{N} V_{c}^{i}}{\sum_{i=1}^{N} D_{\text {tot }}^{i}},
$$

where $E_{\text {pot }}$ is the potential for potable water savings (\%); $V_{c}^{i}$ is the rainwater (or stormwater) volume used in the $i$ day (litres); $D_{\text {tot }}^{i}$ is the total water demand of the $i$ day (litres); and $N$ is the number of days analysed for the system.

The water harvested is the rainwater that falls directly on the pavement surface and the runoff from adjacent areas, with the latter presenting the highest number of pollutants. The infiltrated water is drained by gravity to a lower reservoir that temporarily stores the water and overflows in the case of overload. When users require rainwater, it is supplied from an upper reservoir filled from the lower reservoir using motor pumps. The use of additional water treatment, such as chlorination, is performed in the upper reservoir not to waste chemical products. From Martins Vaz et al. [52], Figure 2 shows an example of a rainwater harvesting model using permeable pavements.

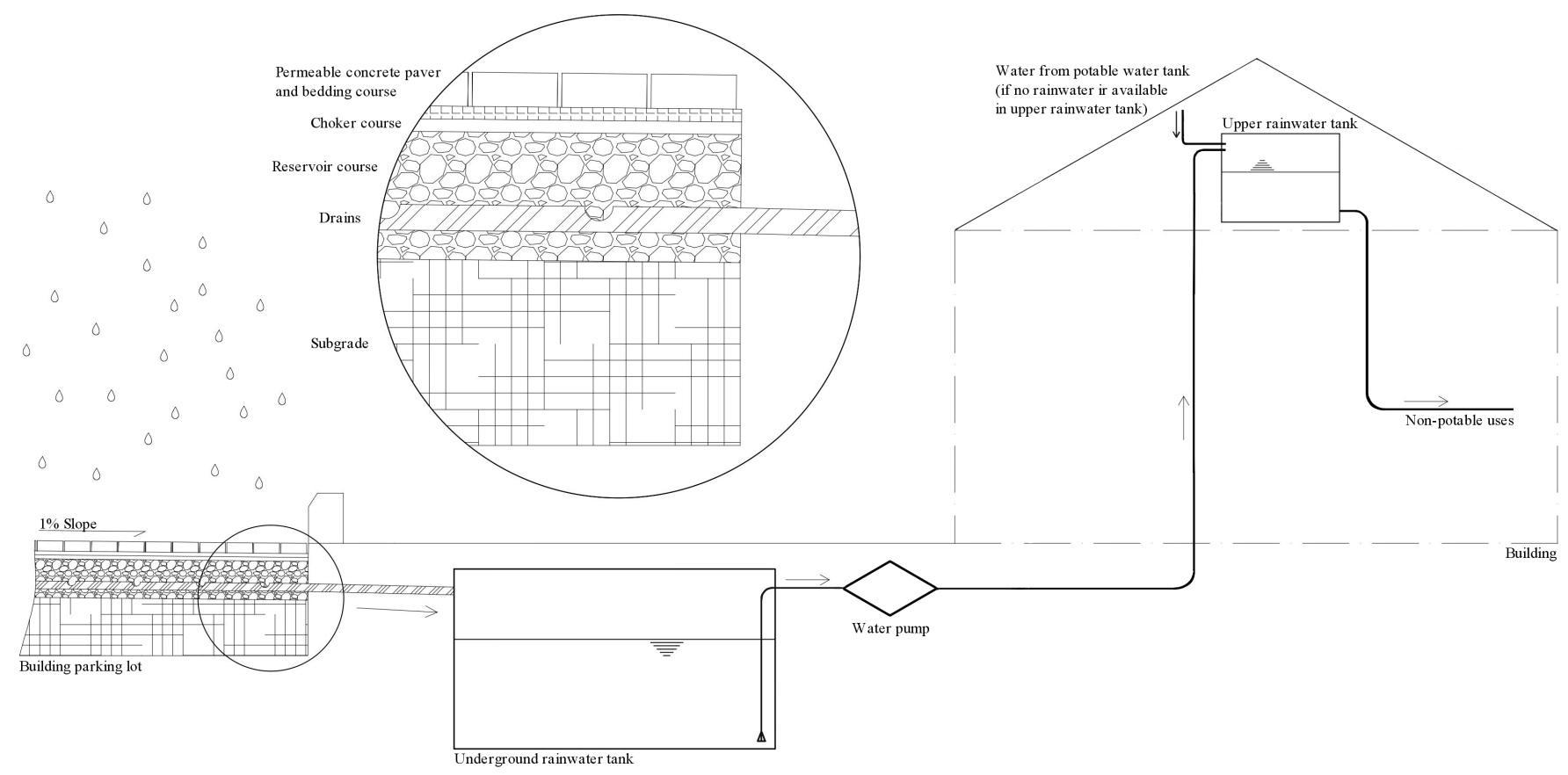

Figure 2. Permeable pavements rainwater harvesting system. Source: Adapted [52].

\subsection{Clogging}

Clogging is a physical-chemical effect of filling the communicating voids of a permeable medium, causing the system's waterproofing. For permeable pavements, the effect is one of the main causes of the decrease in service life due to the decrease in hydraulic capacity and consequent non-compliance with the design principles. Studies that evaluate the service life and methods to reduce the effects of clogging are essential to understand the effectiveness of the system, as well as the establishment of a strict control plan to not prematurely end the pavement efficiency. Permeable coatings and pavements present a high volume of voids, Refs. $[17,48]$ with clogging responsible for filling the communicating voids and consequently decreasing the whole system's permeability.

\subsection{Stormwater Quantity}

The amount of infiltrated water in the permeable pavement is important as it influences the road runoff and the water available for use. Among the selected papers, 
quantitative evaluations were performed to obtain data. Subsequently, the data are used as input parameters to simulate the potential for potable water savings.

\subsection{Stormwater Quality}

Water quality is an essential requirement for the disposal or use of water. During disposal, possible sources of pollution and undesired quality parameters, such as phosphorous compounds, nitrogen compounds and heavy metals, are assessed. Thus, the appropriate treatment is indicated so that the water infiltrated in the permeable pavement can be conducted to the subsoil to recharge the water table. Another possibility is the storage and use of water for non-potable purposes. For this purpose, the qualitative parameters are compared with the Brazilian standards for non-potable use. As the papers evolved, the Brazilian standards were also modified, and the comparative analysis assesses the difference in requirements.

\subsection{LCA, LCEA and LCCA}

Life Cycle Assessment (LCA) is a comparative environmental assessment method widely used to comprehend possible improvements in systems and assist managers in decision-making. The method uses a functional unit, the same type of comparison delivery, in different configurations so that the environmental impacts of design choices are comparable and the most environmentally beneficial configuration can be researched. Life Cycle Energy Assessment (LCEA) is a strand of LCA that looks specifically at the energy inputs and outputs of the system to understand which system requires the most energy. Life Cycle Cost Analysis (LCCA) is a variation of LCA that focuses on input and output processes with monetary value. Assessment by all three methods can provide information to decision-makers who can thus better define the design choices of harvesting systems.

\subsection{Hydraulic and Structural Design}

Permeable pavement effectiveness is based on two needs that must be met regarding the project's design, hydraulic and structural. In hydraulic design, the rainfall of the region and the runoff are evaluated. Based on the rainfall volume, one can evaluate if the structure is sufficient and capable of storing and dissipating the harvested water. Thus, the structure helps to reduce the stress on the urban drainage networks. In structural design, the structure must meet the vehicles' loads without damage or pathological manifestations to the users. In order to comply with both requirements, the correct thickness of all layers must be guaranteed, from which it is usual to use the reservoir layer thickness as variable and higher than the minimum necessary to meet the hydraulic and structural projects. From the sizing, the minimum design thickness for the reservoir layer is obtained.

\section{Results and Discussion}

\subsection{Model Characteristics and Stormwater Quantity}

Antunes et al. [45] analysed the amount of rainwater that could infiltrate in four models of permeable asphalt mixtures. The slabs were differentiated by the type of binder (modified by tyre rubber and by styrene-butadiene-styrene polymer-SBS) and also by the cycling or not of water. The permeable asphalt mixtures were designed with granite aggregates from a quarry localised in southern Brazil [57]. The aggregates were characterised based on Brazilian regulations and were acceptable for the production of asphalt mixtures. The granulometric curve fitted the range IV of the Brazilian standard [58] Tyreflex AB8 asphalt rubber and SBS polymer were used as modifiers. The asphalt content determined by the Superior Performing Asphalt Pavements (SUPERPAVE@ [59]) was equal to $5.0 \%$.

The permeable asphalt mixtures of Antunes et al. [45] (Figure 3a) present high air void percentages and are more susceptible to crumbling than dense mixtures. As a means to assess the resistance to crumbling, the permeable mixtures were exposed to water cycling tests. Two mixtures were assessed with water cycling and the other two without it. The tests 
involve exposing the slabs into three cycles of immersion in a water tank and drying in an oven. The cycles last $16 \mathrm{~h}$, in which, for $8 \mathrm{~h}$, the slabs remain in the water and for another $8 \mathrm{~h}$ drying in an oven at $40^{\circ} \mathrm{C}$.

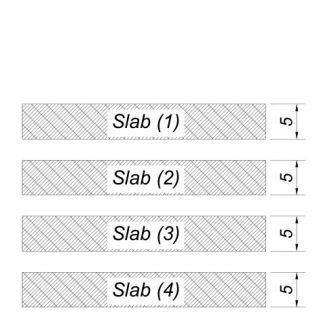

(a)

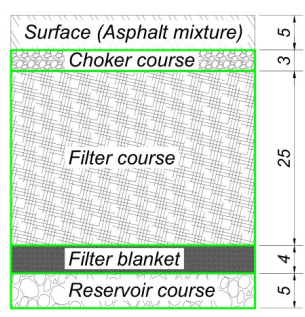

(b)

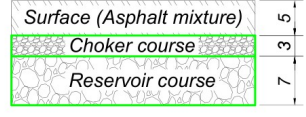

(c)

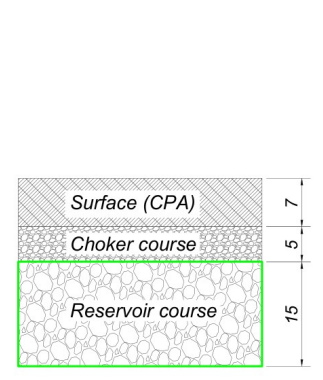

(d)

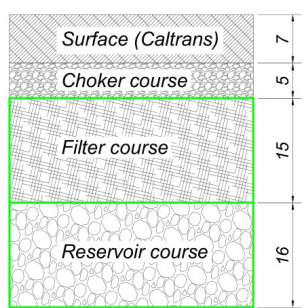

(e)

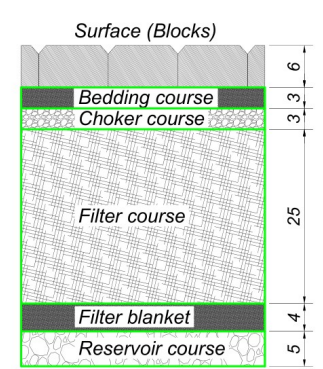

(f)

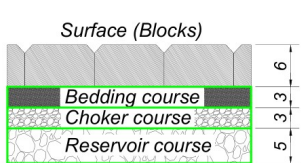

(g)

Figure 3. Permeable pavement models analysed in the selected papers. Source: (a) permeable asphalt mixtures slabs [45]; (b) permeable pavement with filter course [50]; (c) permeable pavement without filter course [50]; (d) permeable pavement without filter course [53]; (e) permeable pavement with filter course [53]; (f) permeable pavement with filter course [49]; (g) permeable pavement without filter course [49]. The figure is based on materials and thicknesses of papers [45,49,50,53]. The green line represents the geotextile use. All dimensions are in centimetres.

The asphalt mixture slabs had dimensions of $50.0 \times 18.0 \times 5.0 \mathrm{~cm}$ and were compacted following the standard NF 98-250-2 [60]. In sequence, the void volume and the interconnected voids were determined according to AASHTO standard R 35 [61] and NF P98-254-2 [62], respectively. The permeability coefficient was evaluated using the LCS permeameter (developed by the Laboratorio Escuela de Caminos de Santander), according to NLT-327 [63]. The percentages of rainwater infiltration by the slabs ranged from $84.3 \%$ to $87.0 \%$. No significant difference was found between the mixtures, with the average $(85.4 \%)$ adopted as the final result for the infiltration percentage.

Hammes et al. [50] analysed models considering all layers of permeable pavement. The coating used was a permeable asphalt mixture modified with Tyreflex AB8 tyre rubber without water cycling [48]. Two models were simulated. Model A (Figure 3b) had a $42 \mathrm{~cm}$ thickness and five layers: coating; choker course; filter course; filter blanket; and reservoir course sized according to the site rainfall characteristics. The thickness of each layer is presented in Figure 3b. Model B (Figure 3c) had $15 \mathrm{~cm}$ thickness and three layers: coating; choker course; and reservoir layer sized according to the site rainfall characteristics. The thickness of each layer is presented in Figure 3c. The materials used for the permeable layers and its characteristics are shown in Table 3.

The results indicated that model A had an average infiltration percentage of $70.1 \%$, while model B obtained $80.0 \%$. The main difference between the models is the sand filtering layer existing in model $\mathrm{A}$. When rainwater infiltrates the layers, the sand retains the water. This process causes the evaporation of part of the infiltrated water. One can notice that, in comparison with the results of Antunes et al. [45], the infiltration percentage of the models of Hammes et al. [50] was considerably lower, mainly due to the retention and evaporation of a part of the water infiltrated into the layers. 
Another study that also assessed different layers of permeable pavements was the research conducted by Thives et al. [53]. Three permeable asphalt mixtures were designed and tested. For the production of the asphalt mixtures, coarse $\left(3 / 4^{\prime \prime}\right.$ and $\left.3 / 8^{\prime \prime}\right)$ and fine $(4.75 \mathrm{~mm})$ granitic aggregates were used. The tests were performed according to DNERME 081/98 [64] and DNER-ME 084/95 [65]. The mixtures were made with 15\% rubber incorporated into the binder and were produced in open gradations.

The particle size curves met the following three specifications: (i) Caltrans [66] —Open Graded Friction Course (OGFC) $1 / 2^{\prime \prime}$, with $23 \%$ voids and $3.5 \%$ binder; (ii) CPA [58]Porous Friction Course, with 29\% voids and 3.5\% binder; and (iii) PMQ-Porous Asphalt Mixture (PMQ-Pre-Hot Mix [67]) with 25\% voids and $4.5 \%$ binder. The thicknesses of the overlay layers of permeable asphalt pavements in Brazil vary from 4 to $8 \mathrm{~cm}$. In the study by Thives et al. [53], the Caltrans and CPA mixtures were cast with $7 \mathrm{~cm}$ thickness and with $5 \mathrm{~cm}$ for the PMQ.

Regarding the remaining permeable layers, two models were simulated. Model A (Figure $3 \mathrm{~d}$ ) was composed of a CPA as coating $(7 \mathrm{~cm})$, PMQ used as course choker $(5 \mathrm{~cm})$, and a reservoir layer composed of simple graded gravel (BGS) $(15 \mathrm{~cm})$. Model B (Figure 3e) was composed of a coating designed according to Caltrans guidelines $(7 \mathrm{~cm})$, choker course $(5 \mathrm{~cm})$, filter course $(15 \mathrm{~cm})$, and a reservoir layer $(16 \mathrm{~cm})$. The results show that the mix with the largest voids (CPA) presented the highest amount of infiltrated stormwater (87.3\%). All permeable asphalt mixtures presented suitable infiltration of rainwater (values always above $67.0 \%)$. On average, model B showed better performance than model A ( $86.4 \%$ against $83.7 \%$ ). Unlike the results observed in the study of Hammes et al. [50], even having a sand layer (filter course), model B obtained a higher percentage of infiltration. Model A has a reservoir layer in gravel with a large number of fines, reducing the drainage capacity which decreases the amount of stormwater infiltrated.

Ghisi et al. [49] also evaluated permeable pavement models and the amount of rainwater they were able to capture. However, unlike the other studies presented so far, this one used interlocking concrete blocks as coating, instead of permeable asphalt mixtures. The blocks are made in industry, following the quality requirements of NBR 9781 [68]. This standard requires that permeable interlocking blocks have a permeability coefficient greater than $10^{-3} \mathrm{~m} / \mathrm{s}$, a minimum compressive strength of $20 \mathrm{MPa}$ and a minimum thickness of $60 \mathrm{~mm}$. The blocks are rectangular, with the following dimensions: length $200 \mathrm{~mm}$, width $100 \mathrm{~mm}$ and thickness $60 \mathrm{~mm}$. The authors performed tests on six random samples. The blocks presented a compressive strength equal to $34.4 \mathrm{MPa}$ and a permeability coefficient equal to $9.34 \times 10^{-3} \mathrm{~m} / \mathrm{s}$, thus meeting the requirements of the Brazilian standard.

Two models were simulated. Model A (Figure 3f) is composed of permeable interlocking concrete blocks $(6 \mathrm{~cm})$, bedding layer $(3 \mathrm{~cm})$, choker course $(3 \mathrm{~cm})$, filter course $(25 \mathrm{~cm})$, filter blanket $(4 \mathrm{~cm})$, and reservoir layer $(5 \mathrm{~cm})$. Model B (Figure $3 \mathrm{~g}$ ) has the same layers and thicknesses, excluding the filter course and filter blanket. The following materials were used: aggregate $(\max .9 .5 \mathrm{~mm})$ for the bedding layer; aggregate $(\max .19 \mathrm{~mm}$ ) for the choker course; commercial sand (max. $4.75 \mathrm{~mm}$ ) for the filter course; aggregate (max. $9.5 \mathrm{~mm}$ ) for the filter blanket; and aggregate $(\max .37 .5 \mathrm{~mm}$ ) for the reservoir layer. Model A had an average infiltration capacity equal to $78.8 \%$ and model B, $88.1 \%$.

As in the study by Hammes et al. [50], the model with the sand layers (model A) obtained a considerably lower infiltration percentage. Comparing the models with different coatings, one can notice that the permeable interlocking block pavements obtained a notably higher infiltration percentage $(88.1 \%)$ when compared to the permeable asphalt mix coating $(80.0 \%)$. Table 3 presents a summary of the characteristics of the permeable pavement models adopted in the studies analysed. One can also observe that the infiltration percentages vary from $70.0 \%$ to $88.1 \%$ according to the layer thicknesses and materials used. 
Table 3. Layers, materials, thicknesses and infiltration of the analysed models.

\begin{tabular}{|c|c|c|c|c|c|}
\hline Study & Model & Layer & Material & Thickness (cm) & Infiltration $(\%)$ \\
\hline \multirow{4}{*}{ Antunes et al. [45] } & 1 & \multirow{4}{*}{ Only surface } & $\begin{array}{l}\text { Porous asphalt mixture with tyre rubber } \\
\text { (without water cycling) }\end{array}$ & \multirow{4}{*}{5} & 85.8 \\
\hline & 2 & & $\begin{array}{l}\text { Porous asphalt mixture with tyre rubber } \\
\text { and water cycling }\end{array}$ & & 84.3 \\
\hline & 3 & & $\begin{array}{l}\text { Porous asphalt mixture with SBS (without } \\
\text { water cycling) }\end{array}$ & & 84.6 \\
\hline & 4 & & $\begin{array}{l}\text { Porous asphalt mixture with SBS and } \\
\text { water cycling }\end{array}$ & & 87 \\
\hline \multirow{8}{*}{ Hammes et al. [50] } & \multirow{5}{*}{ A } & Surface & Porous asphalt mixture with tyre rubber & 5 & \multirow{5}{*}{70.1} \\
\hline & & Choker course & Coarse aggregate $(19 \mathrm{~mm})$ & 3 & \\
\hline & & Filter course & Sand $(4.75 \mathrm{~mm})$ & 25 & \\
\hline & & Filter blanket & Coarse aggregate $(9.5 \mathrm{~mm})$ & 4 & \\
\hline & & Reservoir course & Coarse aggregate $(37.5 \mathrm{~mm})$ & 5 & \\
\hline & \multirow{3}{*}{ B } & Surface & Porous asphalt mixture with tyre rubber & 5 & \multirow{3}{*}{80} \\
\hline & & Choker course & Coarse aggregate $(19 \mathrm{~mm})$ & 3 & \\
\hline & & Reservoir course & Coarse aggregate $(37.5 \mathrm{~mm})$ & 7 & \\
\hline \multirow{7}{*}{ Thives et al. [53] } & \multirow{3}{*}{ A } & Surface & Porous asphalt mixture (CPA) & 7 & \multirow{3}{*}{86.4} \\
\hline & & Choker course & Pre-Hot Mix (PMQ) & 5 & \\
\hline & & Reservoir course & Simple graded gravel (BGS) & 15 & \\
\hline & \multirow{4}{*}{ B } & Surface & Porous asphalt mixture (Caltrans) & 7 & \multirow{4}{*}{83.7} \\
\hline & & Choker course & Coarse aggregate $(19 \mathrm{~mm})$ & 5 & \\
\hline & & Filter course & Sand $(4.75 \mathrm{~mm})$ & 15 & \\
\hline & & Reservoir course & Coarse aggregate $(37.5 \mathrm{~mm})$ & 16 & \\
\hline \multirow{10}{*}{ Ghisi et al. [49] } & \multirow{6}{*}{ A } & Surface & Permeable interlocking blocks & 6 & \multirow{6}{*}{78.8} \\
\hline & & Bedding layer & Coarse aggregate $(9.5 \mathrm{~mm})$ & 3 & \\
\hline & & Choker course & Coarse aggregate $(19 \mathrm{~mm})$ & 3 & \\
\hline & & Filter course & Sand $(4.75 \mathrm{~mm})$ & 25 & \\
\hline & & Filter blanket & Coarse aggregate $(9.5 \mathrm{~mm})$ & 4 & \\
\hline & & Reservoir course & Coarse aggregate (37.5 mm) & 5 & \\
\hline & \multirow{4}{*}{ B } & Surface & Permeable interlocking blocks & 6 & \multirow{4}{*}{88.1} \\
\hline & & Bedding layer & Coarse aggregate $(9.5 \mathrm{~mm})$ & 3 & \\
\hline & & Choker course & Coarse aggregate $(19 \mathrm{~mm})$ & 3 & \\
\hline & & Reservoir course & Coarse aggregate $(37.5 \mathrm{~mm})$ & 5 & \\
\hline
\end{tabular}

\subsection{Harvested Water Quality}

Hammes et al. [50] analysed the pollutant filtering capacity of two permeable pavement models presented in Section 3.1 (Figure 3b,c). Stormwater was collected from runoff of a parking lot in UFSC and tested for pollutants. The harvested rainwater was then poured over the two permeable pavement models, and the filtered water was also tested for pollutants. The amounts of pollutants in the samples were compared to the limits established in Brazil for non-potable purposes (toilet flushing and urinal flushing).

The parameters used in the analysis are those required by the the National Water Agency (ANA, in Portuguese [69]). All the tests followed the recommendations of the Standard Methods for the Examination of Water and Wastewater.

There was an increase in the concentration of some pollutants after rainwater infiltrated the models. The results show that, for non-potable purposes in buildings, infiltrated rainwater requires additional treatment to be used, as required by ANA [69]. The authors found that rainwater disinfection should be done before using any additional treatment, as it nullifies pathogenic microorganisms, algae, and bacteria. The authors indicate that chlorine and ultraviolet (UV) radiation are treatment options.

Model A (with filtering layer) performed better than model B. The greatest reductions were noted for faecal coliforms, colour, turbidity, nitrite and total suspended solids. 
The reduction in $\mathrm{pH}$, according to the authors, is due to the construction sand used in the filtering layer. The average concentration of total suspended solids in the parking lot runoff was $98 \mathrm{mg} / \mathrm{L}$. This high concentration of pollutants is due to solid materials in the unpaved area of the parking lot. The models tested had great ability to reduce the total suspended solids.

Hammes et al. [50] also used another Brazilian standard with quality requirements for different water sources for comparison with the limits established by ANA. The Brazilian standard NBR 13969 [70] establishes the following parameters as requirements use in toilet flushing: (i) turbidity less than $10 \mathrm{NTU}$ and (ii) fecal coliforms less than $500 \mathrm{CFU} / 100 \mathrm{~mL}$. These values are less restrictive when compared to ANA [69] and, according to the authors, rainwater infiltrated by model $\mathrm{A}$ is considered adequate for non-potable uses with such parameters, different from the results obtained by the ANA recommendations. Two other recent Brazilian standards that also present qualitative requirements for non-potable uses are NBR 16783 [55] and NBR 15527 [71]. Both standards bring qualitative parameters to be met, of which NBR 15527 [71] presents less stringent minimum requirements since it deals with harvest through roofs with a consequent lower generation of pollutants.

Thives et al. [53] also analysed the rainwater quality infiltrated by the permeable pavement models presented in Section 3.1. The concentration of phosphorus, iron, aluminium, zinc, nitrite, chromium and copper increased after the stormwater passed through the permeable pavement models. The $\mathrm{pH}$ also increased after stormwater was filtered through the layers. Only phosphorus and aluminium exceeded the recommended limits. Both models were able to filter and reduce ammonia concentrations. No odour or faecal coliforms were detected in the samples. The authors concluded that it is possible to use rainwater filtered by permeable asphalt pavements for non-potable purposes in buildings, provided that additional treatment is used.

Ghisi et al. [49] analysed the quality of stormwater after infiltration in permeable pavement models with interlocking concrete blocks. The model with a sand layer was able to reduce the concentrations of faecal coliforms, total suspended solids, biochemical oxygen demand and total phosphorus concentration. The reductions varied from $42.4 \%$ to $78.8 \%$. On the other hand, the concentrations of biochemical oxygen demand and total phosphorus increased in the model without a sand layer. The concentrations were above the recommended limits in the following parameters: total suspended solids, colour, turbidity and faecal coliforms. The other analysed parameters were in accordance with the requirements of ANA [69]. The authors concluded that the sand layer used in permeable pavements made of interlocking concrete blocks can reduce pollutants and improve the quality of stormwater. The use of this type of pavement showed to be a potential alternative for rainwater filtration before further treatment for non-potable uses in buildings.

Table 4 presents a summary of the results obtained for stormwater quality in the selected studies and the minimum quality requirements. Table 4 also presents the requirements of the Brazilian standards NBR 16783 and 15527, although they are not the scope of evaluation within the selected articles. 
Table 4. Qualitative parameters of the selected papers.

\begin{tabular}{|c|c|c|c|c|c|c|c|c|c|c|c|c|c|}
\hline \multirow{2}{*}{ Parameters } & \multicolumn{4}{|c|}{ Limit Values } & \multicolumn{3}{|c|}{ Hammes et al. [50] } & \multicolumn{3}{|c|}{ Thives et al. [53] } & \multicolumn{3}{|c|}{ Ghisi et al. [49] } \\
\hline & ANA [69] & NBR 15527 [71] & NBR 16783 [55] & CONAMA $[72,73]$ & Runoff & Model A & Model B & Runoff & Model A & Model B & Runoff & Model A & Model B \\
\hline E. coli & - & $<200 / 100 \mathrm{~mL}$ & $<200 / 100 \mathrm{~mL}$ & - & na & na & na & - & - & - & - & - & - \\
\hline Faecal coliforms & nd & - & - & - & 1020 & 6.5 & 352 & - & - & - & 1716.5 & 777.8 & 1493.6 \\
\hline $\mathrm{pH}$ & $6.0-9.0$ & $6.0-9.0$ & $6.0-9.0$ & - & 7.6 & 5.3 & 7.4 & 6.9 & 7.6 & 7.6 & 8 & 6.7 & 8.3 \\
\hline Colour & $\leq 10 \mathrm{HU}$ & - & - & - & 144 & 5 & 146 & - & - & - & 179 & 172 & 151 \\
\hline Turbidity & $\leq 2 \mathrm{NTU}$ & $<5.0 \mathrm{uT}$ & $<5.0 \mathrm{uT}$ & - & 51.7 & 1.7 & 23.2 & - & - & - & 31.2 & 26.9 & 17.9 \\
\hline Odour and aspect & nu & - & - & - & $\mathrm{u}$ & nu & $\mathrm{u}$ & - & - & - & $\mathrm{nu}$ & $\mathrm{nu}$ & $\mathrm{nu}$ \\
\hline Oil and grease & $\leq 1 \mathrm{mg} / \mathrm{L}$ & - & - & - & 1 & na & na & - & - & - & nd & nd & nd \\
\hline BOD & $\leq 10 \mathrm{mg} / \mathrm{L}$ & - & $\leq 20 \mathrm{mg} / \mathrm{L}$ & - & 8.2 & 5 & 8 & - & - & - & 3.3 & 0.7 & 4.7 \\
\hline Nitrate & $<10 \mathrm{mg} / \mathrm{L}$ & - & - & - & 0.28 & 0.52 & 0.3 & - & - & - & 0.33 & 0.72 & 0.92 \\
\hline Ammoniacal nitrogen & $\leq 20 \mathrm{mg} / \mathrm{L}$ & - & - & - & 0.67 & 0.8 & 0.95 & 0.36 & 0.2 & 0.14 & 0.83 & 1.12 & 1.37 \\
\hline Nitrite & $\leq 1 \mathrm{mg} / \mathrm{L}$ & - & - & - & 0.04 & 0.01 & 0.06 & 0.36 & 0.2 & 0.14 & 0.05 & 0.06 & 0.12 \\
\hline Total phosphorus & $\leq 0.1 \mathrm{mg} / \mathrm{L}$ & - & - & - & 0.4 & 0.31 & 0.17 & 0.92 & 1.26 & 3.19 & 0.18 & 0.08 & 0.26 \\
\hline Total suspended solids & $\leq 5 \mathrm{mg} / \mathrm{L}$ & - & $\leq 2000 \mathrm{mg} / \mathrm{L}$ & - & 98 & 8 & 17 & - & - & - & 16 & 6 & 7 \\
\hline Iron & - & - & - & $\leq 15.00$ & - & - & - & 0.54 & 0.81 & 2.12 & - & - & - \\
\hline Aluminium & - & - & - & $\leq 0.10$ & - & - & - & 0.05 & 0.13 & 0.18 & - & - & - \\
\hline Zinc & - & - & - & $\leq 5.00$ & - & - & - & 0.04 & 0.08 & 0.11 & - & - & - \\
\hline Copper & - & - & - & $\leq 1.00$ & - & - & - & 0.32 & 0.3 & 0.37 & - & - & - \\
\hline OVC & $<\mathrm{dL}$ & - & - & - & - & - & - & - & - & - & $<\mathrm{dL}$ & $<\mathrm{dL}$ & $<\mathrm{dL}$ \\
\hline
\end{tabular}

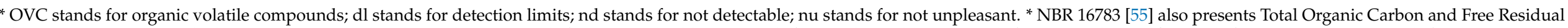

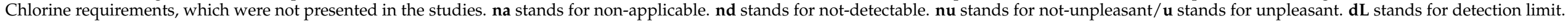

uT stands for units of Turbidity/NTU stands for Nephelometric Turbidity Units/HU stands for Hazen Units. 
In summary, one can conclude that water quality for non-potable purposes in Brazil is related to only five parameters, which do not include rubber parts of tires, heavy metals, oil and grease, phosphorus, or nitrogen. However, studies in the literature, including the papers analysed in this review, show that permeable pavements improve water quality in these parameters. Regarding heavy metals, studies [74,75] have proven the ability of permeable pavements to reduce the final concentration. As for rubber parts of tires, the parameter is indirectly included in turbidity analysis. Further investigations related to the long-term use of stormwater harvested are indicated to best analyse the effects of stormwater elements that may lead to premature pathologies in the system.

Another topic of relevance is the ability of pavements to clean the air through nano-particles. Some studies [76,77] have analysed the use of photo-catalytic elements in permeable pavements, with the addition of particles of $\mathrm{TiO}_{2}$ and $\mathrm{ZnO}$. The possibility to clean the air in urban spaces and better filtrate the stormwater are some of the benefits aimed with the inclusion of the technology. Future research on the field should cover the effect of car pollution on stormwater quality and the analysis of permeable pavements with the presence of these components.

\subsection{Potential for Potable Water Savings}

Many of the studies developed by UFSC on permeable pavements considered the use of rainwater infiltrated into the pavement for non-potable uses in buildings, such as toilet flushing, urinals, outdoor cleaning and garden irrigation. The studies were conducted considering urban scales (implementation of permeable pavement in urban roads with light traffic) or smaller scales (implementation of permeable pavement in car parks of buildings). Furthermore, different types of buildings were considered in the case studies (residential, commercial and public).

For the design of the rainwater reservoir volume and the potential for potable water savings, the authors used the computational programme Netuno 4 [56]. Rocha [78] validated the programme as a tool to assess rainwater harvesting and address the potential for potable water savings. The main method of Netuno 4 performs simulations on a deterministic approach on water balance.

For the studies performed under the implementation of permeable pavement in parking lots, stormwater tank volumes ranged from 9 to $50 \mathrm{~m}$, with the potential for potable water savings ranging between $18.5 \%$ and $82.8 \%$. These studies were carried out in public buildings (universities and public offices), in which rainwater demands are high $(69.0 \%$ to $85.0 \%)$, showing great potential for saving potable water. Among the locations assessed, five of the seven studies evaluating potential for potable water savings were located only in Florianópolis, the others referring to the city of Glasgow, Scotland, and a parametric study evaluating eight Brazilian cities, namely Florianópolis, Porto Alegre, Curitiba, São Paulo, Belo Horizonte, Manaus, Recife and Brasília. As observed by Martins Vaz et al. [52], the rainfall directly influences the results and should be considered.

In the studies that considered a macro scale implementation (permeable pavement in urban public roads of light traffic), the authors considered reservoirs distributed by communities (neighbourhoods) to decentralise the water treatment and distribution system. The stormwater reservoirs had a capacity ranging from 500 to $1000 \mathrm{~m}$. The potential for potable water savings ranged from $19.3 \%$ to $75.7 \%$, according to the type of occupation. The results show that, in the case studies carried out, the stormwater demand of the buildings was the most influential parameter in the potential for potable water savings. The savings potential ranged from $19.3 \%$ to $34.5 \%$ in residential buildings, while commercial and public buildings had higher Figures (70.0\% and $75.7 \%$, respectively). It should be noted that public and commercial buildings have a high demand for non-potable water, mainly for flushing toilets and urinals, while, in residential buildings, the demand for non-potable water is lower due to the high consumption of potable water in showers, sinks, kitchen sinks, and washing machines, among others.

Other parameters also influenced reservoir design and the potential for potable water savings, such as local rainfall, pavement area (harvesting area) and infiltration rate. Table 5 presents a summary of the parameters used and the results obtained in each study. 
Table 5. Potential for potable water savings and simulations of the selected papers.

\begin{tabular}{|c|c|c|c|c|c|c|c|c|c|}
\hline Paper & City & $\begin{array}{c}\text { Annual } \\
\text { Rainfall (mm) }\end{array}$ & Pavement Type & $\begin{array}{c}\text { Infiltration Rate } \\
(\%)\end{array}$ & Type of Use & Area $\left(m^{2}\right)$ & $\begin{array}{c}\text { Reservoir } \\
\text { Capacity }\left(\mathrm{m}^{3}\right)\end{array}$ & $\begin{array}{c}\text { Final } \\
\text { Non-Potable } \\
\text { Uses (\%) }\end{array}$ & $\begin{array}{c}\text { Potential for } \\
\text { Potable Water } \\
\text { Savings (\%) }\end{array}$ \\
\hline \multirow{2}{*}{ Antunes et al. [45] } & \multirow{2}{*}{ Florianópolis } & \multirow{2}{*}{1766} & Considered only the & \multirow{2}{*}{85.4} & \multirow{2}{*}{$\begin{array}{l}\text { Residential } \\
\text { Public } \\
\text { Commercial }\end{array}$} & \multirow{2}{*}{11,044} & \multirow{2}{*}{1000} & 19.4 & 19.4 \\
\hline & & & with SBS and tyre rubber) & & & & & 70.0 & 70.0 \\
\hline \multirow{3}{*}{ Hammes et al. [50] } & \multirow{3}{*}{ Florianópolis } & \multirow{3}{*}{1720} & $\begin{array}{l}\text { Model A: CPA, choker } \\
\text { course, filter course, filter }\end{array}$ & 70.1 & \multirow{3}{*}{ University } & \multirow{3}{*}{5500} & \multirow{3}{*}{45} & \multirow{3}{*}{69.0} & 53 \\
\hline & & & blanket, reservoir layer & & & & & & \\
\hline & & & $\begin{array}{l}\text { Model B: CPA, choker } \\
\text { course, reservoir layer }\end{array}$ & 80.0 & & & & & 54 \\
\hline Thives et al. [54] & Florianópolis & 1607 & Impermeable & $\begin{array}{l}0.90 \text { (runoff } \\
\text { coefficient) }\end{array}$ & Residential & $9058 \pm 10 \%$ & 1000 & 20,30 and 40 & 19.3 to 33.4 \\
\hline Antunes et al. [46] & Florianópolis & 1764 & $\begin{array}{c}\text { Model B of } \\
\text { Hammes et al. [50] }\end{array}$ & 80.0 & Public & 5800 & 50 & 82.0 & 69.6 \\
\hline Antunes et al. [47] & Glasgow & 1032 & $\begin{array}{c}\text { Model B of } \\
\text { Hammes et al. [50] }\end{array}$ & 80.0 & Residential & 28,505 & 500 & 37.0 & 34.5 \\
\hline \multirow{2}{*}{ Martins Vaz et al. [51] } & \multirow{2}{*}{ Florianópolis } & \multirow{2}{*}{1662} & Model of Acioli [79] & 94.9 & \multirow{2}{*}{ University } & \multirow{2}{*}{1700} & \multirow{2}{*}{20} & \multirow{2}{*}{69.0} & 43.6 \\
\hline & & & Model of Pinto [80] & 88.0 & & & & & 42.9 \\
\hline Martins Vaz et al. [52] & $\begin{array}{l}\text { Eight Brazilian } \\
\text { cities }\end{array}$ & $\begin{array}{l}\text { Variable in each } \\
\text { city }\end{array}$ & Model B of Ghisi et al. [49] & 88.1 & University & $\begin{array}{c}\text { Variable in six } \\
\text { different buildings }\end{array}$ & 9 to 24 & 69,77 and 85 & 18.4 to 84.8 \\
\hline
\end{tabular}




\subsection{Hydraulic and Structural Design}

Hammes et al. [50] performed the hydraulic sizing of the reservoir layer of the permeable pavement in their study. The thickness was defined based on manuals and standards [81] that indicate the evaluated parameters such as: the intensity of the design precipitation, the duration of the design rainfall, the ratio between the drained area and the area of the permeable pavement, the porosity of the reservoir layer and the specific outlet flow. As a result, the authors obtained a thickness of $22 \mathrm{~cm}$, with Florianópolis rainfall data, a return period of five years and a design rainfall duration of $60 \mathrm{~min}$. The drainage specific outlet flow considerations of Hammes et al. [50] refer to the continuous dissipation of water, with a constant figure, during the emptying period of the reservoir layer.

Martins Vaz et al. [51] performed the hydraulic sizing with a similar method to that of Hammes et al. [50]. The authors also evaluated the use of an alternative method of hydraulic pre-design with the name of the envelope curve method [82]. As a result, the authors concluded that the method of Hammes et al. [50] generates slightly more slender thicknesses than the envelope curve method. They also comment on the need to evaluate the slopes of the pavement so that, in long stretches of slope, water accumulation does not occur in the lower regions, decreasing the hydraulic storage capacity.

Martins Vaz et al. [52] compared hydraulically the model of Hammes et al. [50] with the water balance results evaluated through the computational programme Permeable Design Pro. As a result, they obtained that considering constant specific flow rate is quite in favour of safety, generating larger thicknesses for the reservoir layer. The drainage model impacts the design considerations and must be verified in each case. For the authors' evaluations, in eight different Brazilian cities, the thickness required for water storage was exceeded by the structural one, i.e., the greater requirements must be met for the pavement to be effective.

Equations (2) and (3) show the calculation model for Hammes et al. [50], as presented by Martins Vaz et al. [52]:

$$
H_{r c}=\frac{\frac{t}{60} \times\left(R \times i-q_{s} \times 1000\right)}{\eta},
$$

where $H_{r c}$ is the reservoir course sized thickness $(\mathrm{mm}) ; t$ is the design rainfall duration (min); $R$ is the ratio between the total area of catchment to the permeable area (dimensionless); $i$ is the average maximum intensity of the design rainfall $(\mathrm{mm} / \mathrm{h}) ; q_{s}$ is the constant specific outlet flow of the pavement $(\mathrm{m} / \mathrm{h})$; and $\eta$ is the porosity of the reservoir course (dimensionless):

$$
q_{s}=\frac{i \times t \times A_{t o t}}{A_{p e r} \times T E \times 1000},
$$

where $q_{s}$ is the constant specific outlet flow of the pavement $(\mathrm{m} / \mathrm{h}) ; i$ is the average maximum intensity of the design rainfall $(\mathrm{mm} / \mathrm{h}) ; t$ is the design rainfall duration, considered equal to $1 \mathrm{~h}$ according to Brazilian standards (h); $A_{\text {tot }}$ is the total catchment area $\left(\mathrm{m}^{2}\right) ; A_{\text {per }}$ is the permeable pavement area $\left(\mathrm{m}^{2}\right)$; and $T E$ is the necessary time to fully empty the reservoir course $(h)$.

Antunes et al. [46] sized the reservoir layer of their design by means of the equations of the Brazilian standard NBR 16416 [83], with a return period of 10 years and design rainfall duration of $60 \mathrm{~min}$. The return time of 10 years is quoted as the minimum of NBR 16416, differing from the consideration of Hammes et al. [50]. Equation (4) shows the calculation model of the Brazilian standard. Antunes et al. [47] sized the layer by means of the methodology indicated by the American Society of Civil Engineers (ASCE), which is equal to Equation (2) used by Hammes et al. [50]:

$$
H_{\text {max }}=\frac{\left(\Delta Q_{c} \times R+P-f \times T_{e}\right)}{V_{r}},
$$


where $H_{\max }$ is the reservoir course sized thickness (m); $\Delta Q_{c}$ is the excess precipitation of the total area for a given design rainfall $(\mathrm{m}) ; R$ is the ratio between the contribution area and the permeable pavement area $\left(A_{c} / A_{p}\right) ; A c$ is the contribution area $\left(\mathrm{m}^{2}\right) ; A p$ is the permeable pavement area $\left(\mathrm{m}^{2}\right) ; P$ is the design rainfall precipitation $(\mathrm{m}) ; f$ is the soil infiltration rate $(\mathrm{m} / \mathrm{h}) ; T_{e}$ is the effective filling time of the reservoir layer, generally equal to $2 \mathrm{~h}(\mathrm{~h})$; and $V_{r}$ is the void ratio of the layer (dimensionless).

Similar analysis was performed in all selected works, with small variations in the calculation approach. The choice of constant specific flow proved to be very favourable to safety and should be further evaluated to understand the chosen thickness's effectiveness. Executive project conditions should also be evaluated, such as the presence of main and secondary drains and the hydraulic flow of the drainage.

Martins Vaz et al. [52] was the only selected work to address the design calculation method regarding structural sizing. The authors evaluated the design through two methods: the American Association of State Highway and Transportation Officials (AASHTO) and the Brazilian Association of Portland Cement (ABCP). As a result, they concluded that the AASHTO method can portray more thoroughly the evaluated model, with the parameter of emptying time of the reservoir layer present in the calculation model. They also concluded for subgrades CBR values above $15 \%$ that the minimum thickness of $10 \mathrm{~cm}$ can structurally meet the model, for both methods, in the case study of a parking lot. The ABCP model does not indicate the presence of additional layers, such as the choker course, and does not have a parameter for the expulsion of water from the reservoir layer, obtaining results similar to the curves of good and optimum drainage of the AASHTO model.

\subsection{Environmental Burden of Systems}

Antunes et al. [46] elaborated a method using Life Cycle Assessment (LCA) in order to assess the environmental sustainability of a permeable pavement system with a rainwater harvest system for non-potable uses in a building. The authors compared two water supply and drainage systems. One of the systems consisted of a permeable pavement, in which rainwater filtered through the pavement was meant to be used for non-potable purposes in a building. The other system consisted of an impermeable pavement and conventional water supply.

The LCA performed was divided into four phases: objective and scope, inventory (LCI), impact assessment (LCIA) and interpretation. The impacts at the different stages of the systems life cycle were assessed (deployment, operation, maintenance and end-of-life). The ReCiPe [84] method was used in the impact assessment phase. ReCiPe is a method for the conversion of life cycle inventories to environmental impact scores in levels of assessment of midpoint and endpoint [84,85]. Fifteen midpoint categories (global warming, ozone layer depletion, fine particle formation, acidification, ecotoxicity, mineral and fossil resource scarcity, among others) were assessed, and these were grouped into endpoint categories (human health, ecosystem quality and resource scarcity).

Implementation and end-of-life stages were the most significant damages for both analysed systems. The high impacts observed for the initial and end-of-life effects are mainly explained by the high consumption of petroleum products (such as asphalt binders and asphalt membranes). Furthermore, the high consumption of aggregates and the energy consumed for the extraction, processing of the materials and transportation of the materials makes these two stages of great impact.

The permeable pavement system showed lower potential for environmental impacts in fourteen of the fifteen midpoint categories and also lower impact potential in the endpoint overall approach. Fine particulate formation matter and global warming categories had the highest environmental impacts for both systems.

In the scenario with permeable pavement and rainwater harvesting, it was concluded that $87.8 \%$ of the potential impacts were generated by permeable pavement, with the remaining $12.2 \%$ generated by the building's rainwater harvesting and potable water supply 
systems. The most impacting processes in the life cycle of permeable pavement are: final disposal $(31.0 \%)$, aggregates $(21.3 \%)$, transportation $(13.1 \%)$ and asphalt binder $(11.6 \%)$.

In the conventional scenario, it was verified that the conventional pavement, added to the drainage devices, was responsible for $95.7 \%$ of the total impacts generated. Of this percentage, $51.8 \%$ was due to the life cycle of the hot-machined bituminous concrete (CBUQ, in Portuguese). The process of manufacturing the asphalt coating uses many oil derivatives, making this process impactful. Transportation $(15.4 \%)$ and final disposal $(12.4 \%)$ also contributed significantly to the potential impacts of the scenario.

Antunes et al. [47] also conducted an LCA study of the use of permeable pavements with rainwater harvesting, comparing it with an impermeable pavement system and conventional water supply. However, unlike the Antunes et al. [46] study, the author considered the use of permeable pavement on a large scale (on light traffic streets and pavements). The city of Glasgow was chosen as a case study. Large reductions in life cycle emissions were observed (equivalent emissions of $\mathrm{CO}_{2}, \mathrm{SO}_{2}$ and $\mathrm{PM}_{2.5}$, among others), and the proposed system was also shown to be economically viable, with payback equal to 16.9 years. When used on a large scale, the results show permeable pavements' economic and environmental viability.

Martins Vaz et al. [51] performed the LCEA and LCCA of a rainwater harvesting system by means of permeable pavements. The model, similarly to that of [46], used the permeable asphalt coating and evaluated three layer systems proposed in the Brazilian literature $[50,79,80]$. As a result, the authors obtained that the permeable pavement harvesting system proved to be more economically advantageous when analysed comparatively with a system composed of impermeable paving. In terms of LCEA, the authors concluded that the energy benefits by reducing potable water consumption are much lower than the energy expenses in manufacturing, transportation and construction of the pavement and hydraulic systems. A comparative model in energy value was not carried out, and the authors only justified the non-possibility of obtaining a net-zero energy system, as embodied energy was much higher than the use phase energy. It is recommended to continue the research of LCA, and its variants, of permeable pavements and their potential to harvest rainwater, including research of other types of permeable coatings, such as the use of Portland cement concrete interlocking blocks.

\subsection{Clogging, Maintenance and Operational Aspects}

Garcia et al. [48] was the only selected paper that mainly evaluated aspects of pavement clogging and durability. The authors' objective was to evaluate the impacts of clogging and traffic on the reduction of the communicating voids and the permeability of permeable asphalt pavements. There is concern about clogging of the voids, leading to a partial loss of permeable function and pavement efficiency.

The authors found that the intervention for maintenance of the permeability of the coating should be done annually. The authors evaluated a series of coatings with different conditions of use and obtained the maximum average time of the first intervention to 12 months. They also evaluated different traffic conditions and compaction values to assess the effects of time on the void content of the coating and the clogging. In general, with greater compaction, there was a reduction in the volume of voids until reaching a minimum level. The increase in compaction or the number of cycles of vehicle traffic after reaching the minimum level did not cause a reduction in void content.

Antunes et al. [46] indicate the need to vacuum the permeable pavement twice a year, in order to maintain permeability, a more conservative measure than the one indicated by Garcia et al. [48]. In addition, the environmental impacts of pavement maintenance were not great compared to the other steps of the project. Antunes et al. [47] used the same consideration of two maintenance with vacuum suction per year. Hammes et al. [50] mention that cleaning by vacuuming the pavement should be done 1 to 4 times per year. Martins Vaz et al. [51] commented on the need for pavement cleaning and included three annual cleanings in the LCEA and LCCA they performed. 
All papers state similar periods of maintenance, between 2 and 3 times a year. In addition, the considerations favour pavement safety and durability, as the Garcia et al. [48] study states once a year as the minimum period required. All research works emphasised the difficulty of finding Brazilian companies specialized in cleaning permeable pavements. Usually, the maintenance recommendations were obtained from international standards and documents, based on the use of equipment found internationally for cleaning, such as the vacuum sweeper truck. It is recommended in future work to evaluate the standard cleaning conditions in Brazil in order to understand the difference that the cleaning mode exerts on pavement durability.

\section{Conclusions}

Permeable pavements are widely studied worldwide, and numerous studies have proven the potential of using the technique to assist urban planning in achieving aspects of sustainability and resilience to climate change. The possibilities of filtering pollutants, dissipating urban runoff with lower velocity, reducing road-noise, helping to combat urban heat islands, among other benefits, are examples of desired characteristics when implementing permeable pavements in urban roads. This study aimed to analyse the main topics evaluated at UFSC, in the area of permeable pavements, by reading ten documents produced in the last six years.

The first two topics evaluated were the quality and quantity of infiltrated water. As for quantity, the aim was to define the amount of water retained in the pavement by absorption of the materials or evaporated. This parameter is important because it correlates with the amount of water received by the drainage, infiltrated into the subgrade or harvested for reuse, impacting the design and analysis of hydraulic flow. In general, the studies obtained similar results, ranging between 70 and $88 \%$ of infiltration rate including different types of coating, i.e., Portland cement concrete blocks and asphalt concrete slabs. In general, estimates above $80 \%$ were found, except for works that include the sand layer, which retained much of the water.

Quality was evaluated to compare the efficiency of the pavements in retaining unwanted compounds and the suitability of the qualitative parameters for specific requirements of use. Through the reading of the papers, it can be seen that different standards can be applied to define control parameters, the two most current being Brazilian standards NBR 15527 and 16783. Both have similar requirements, with 16783 being more rigorous because it deals with various means of water harvesting in a generic approach. The main conclusion is that the use of permeable pavement alone is not enough to meet the requirements of turbidity, $\mathrm{pH}$ and Escherichia coli for non-potable uses. Thus, additional treatments are needed for use in buildings, as concluded by all the authors evaluated. However, in general terms, the consensus is that the use of the sand layer can improve many of the parameters, acting as a pre-filter of the runoff water. It is recommended to maintain the research on the subject with further investigations about the effects of pavement design on the final water quality and possible integrations with different types of treatment for final quality consistent with the proposed use.

After evaluating water quality and quantity parameters, many of the studies focused on evaluating the potential for potable water savings through the use of stormwater for non-potable demands. The design conditions vary greatly between the papers evaluated, with studies on urban streets or parking lot catchments, different building sectors, different harvesting areas, and desired end uses. The amplitude of input variables makes a single conclusion about the potential for adopting the technique complex but can provide knowledge about the variability of the figures obtained. Of the seven studies that evaluated the potential for potable water savings, four focused on parking lots and consequent use in the nearest building, and three focus on large-scale studies with the application for harvesting runoff water from urban roads.

One can conclude that the implementation of systems similar to the one proposed by the authors can supply a large part of the non-potable demand of a building, reaching 
potable water savings of up to $80 \%$. For the residential sector, the non-potable water end-uses represent a smaller portion of the total water use, resulting in a lower potential for potable water savings. For other sectors, public, commercial and university, the nonpotable end uses varied between 69 and $85 \%$, which consequently helped in obtaining greater potential for potable water savings. In general, the large amount of water harvested can be used for non-potable purposes, and permeable pavements can supply such demand, provided that the water capture and storage systems are correctly sized.

Regarding the clogging, maintenance and durability of the permeable pavement, only one of the studies effectively evaluated the conditions. The other studies carried out literature research to justify the conditions of design, LCA and durability of the proposed system. The general conclusion is that permeable pavements can maintain the permeability of the system provided that the maintenance and rehabilitation of the coating are properly scheduled. The maintenance standards converge to two to three times a year, and rehabilitation is necessary once the pavement presents clogging. In future studies, it is recommended to evaluate the effectiveness of rehabilitation and assess the impact of different maintenance methods that are different from the international standards of vacuum suction, which is a technique rarely found in Brazil.

Three of the selected studies carried out evaluations of LCA, LCEA and LCCA, with similar scopes. The three papers evaluated rainwater harvesting systems through permeable pavements and thus considered pavement and hydraulic systems necessary for an efficient operation. Two of them focused on analysing parking lots at a micro-scale, while one carried out a larger approach using the system in urban roads, i.e., macro-scale. The main conclusions of the three works refer to the possibility of obtaining more sustainable and economical systems than the current models of paving, drainage and water supply, provided they are correctly sized and evaluated. The studies focus on models with asphalt concrete coating, thus limiting comparisons and suggesting, for future works, the evaluation of models using permeable interlocking concrete blocks and other types of permeable coatings. They are also quite limited to the regions of analysis, which can be better explored in future works with the analysis of different sites.

In general, the state of the art of permeable pavement studies refers to the future holistic analyses to be carried out in sustainability and resilience models for urban management. The possibility of joining functions and guaranteeing benefits through integrated systems is a tool that should be used to obtain more resilient and prepared cities for climate change. It is also mentioned that many of the evaluated works have justification based on climate change and the need to reassess the urban drainage models to diminish the peak flow. Other benefits, such as traffic noise reduction, runoff reduction and effects on urban heat islands, were also not incorporated in the selected papers and can, as they should, be explored by future works of LCA. It is hoped that LCA will serve as a tool for comparison, incorporating other benefits not considered in the analyses, which, in the current assessment, already justify environmentally, economically and energetically the adoption of permeable pavements and rainwater harvesting.

Author Contributions: Conceptualization, I.C.M.V., L.N.A., E.G. and L.P.T.; methodology, I.C.M.V., L.N.A., E.G. and L.P.T.; writing—original draft preparation, I.C.M.V. and L.N.A.; writing—review and editing, I.C.M.V., L.N.A., E.G. and L.P.T.; supervision, E.G. All authors have read and agreed to the published version of the manuscript.

Funding: This research received no funding.

Institutional Review Board Statement: Not applicable.

Informed Consent Statement: Not applicable.

Data Availability Statement: Not applicable.

Acknowledgments: We would like to thank UFSC for the support. The first and second authors are thankful for Coordenação de Aperfeiçoamento de Pessoal de Nível Superior (CAPES) for the scholarship during this research. 
Conflicts of Interest: The authors declare no conflict of interest.

\section{References}

1. Max Roser, H.R.; Ortiz-Ospina, E. World Population Growth. Our World in Data. 2013. Available online: https: / / ourworldindata. org/world-population-growth (accessed on 15 August 2021).

2. Tzanakakis, V.A.; Paranychianakis, N.V.; Angelakis, A.N. Water Supply and Water Scarcity. Water 2020, 12, 2347. [CrossRef]

3. Boretti, A.; Rosa, L. Reassessing the projections of the World Water Development Report. NPJ Clean Water 2019, 2, 1-6. [CrossRef]

4. Liu, J.; Yang, H.; Gosling, S.N.; Kummu, M.; Flörke, M.; Pfister, S.; Hanasaki, N.; Wada, Y.; Zhang, X.; Zheng, C.; Alcamo, J.; Oki, T. Water scarcity assessments in the past, present, and future. Earth's Future 2017, 5, 545-559. [CrossRef]

5. Muller, M. Cape Town's drought: Don't blame climate change. Nature 2018, 559, 174-176. [CrossRef]

6. Soriano, É.; De Resende Londe, L.; Di Gregorio, L.T.; Coutinho, M.P.; Santos, L.B.L. Water crisis in são paulo evaluated under the disaster's point of view. Ambiente E Soc. 2016, 19, 21-42. [CrossRef]

7. Riswan, M.; Bushra Beegom, R.K. Water Scarcity in Urban Water Supply System: A Case of Thirukkovil, Sri Lanka; Technical Report 1; Faculty of Arts and Culture, South Eastern University of Sri Lanka: Oluvil, Sri Lanka, 2019.

8. Burt, T.; Boardman, J.; Foster, I.; Howden, N. More rain, less soil: Long-term changes in rainfall intensity with climate change. Earth Surf. Process. Landf. 2016, 41, 563-566. [CrossRef]

9. Butler, D.; Ward, S.; Sweetapple, C.; Astaraie-Imani, M.; Diao, K.; Farmani, R.; Fu, G. Reliable, resilient and sustainable water management: The Safe \& SuRe approach. Glob. Chall. 2017, 1, 63-77. [CrossRef] [PubMed]

10. Semadeni-Davies, A.; Hernebring, C.; Svensson, G.; Gustafsson, L.G. The impacts of climate change and urbanisation on drainage in Helsingborg, Sweden: Combined sewer system. J. Hydrol. 2008, 350, 100-113. [CrossRef]

11. Ellis, J.B. Sustainable surface water management and green infrastructure in UK urban catchment planning. J. Environ. Plan. Manag. 2013, 56, 24-41. [CrossRef]

12. Fenner, R. Spatial evaluation of multiple benefits to encourage multi-functional design of sustainable drainage in Blue-Green cities. Water 2017, 9, 953. [CrossRef]

13. Zhong, R.; Leng, Z.; Sun Poon, C. Research and application of pervious concrete as a sustainable pavement material: A state-of-the-art and state-of-the-practice review. Constr. Build. Mater. 2018, 183, 544-553. [CrossRef]

14. Balbo, J.T. Permeable Concrete Pavements-An Environmental View of Emerging Sustainable Technology (Pavimentos de Concreto Permeáveis_Uma visão Ambiental da Tecnologia Sustentável Emergente, in Portuguese), 1st ed.; Oficina de Textos: São Paulo, Brazil, 2020; p. 176.

15. Xie, N.; Akin, M.; Shi, X. Permeable concrete pavements: A review of environmental benefits and durability. J. Clean. Prod. 2019, 210, 1605-1621. [CrossRef]

16. Khankhaje, E.; Salim, M.R.; Mirza, J.; Salmiati.; Hussin, M.W.; Khan, R.; Rafieizonooz, M. Properties of quiet pervious concrete containing oil palm kernel shell and cockleshell. Appl. Acoust. 2017, 122, 113-120. [CrossRef]

17. Knabben, R.M.; Trichês, G.; Gerges, S.N.; Vergara, E.F. Evaluation of sound absorption capacity of asphalt mixtures. Appl. Acoust. 2016, 114, 266-274. [CrossRef]

18. Legret, M.; Colandini, V.; Le Marc, C. Effects of a porous pavement with reservoir structure on the quality of runoff water and soil. Sci. Total Environ. 1996, 189-190, 335-340. [CrossRef]

19. Legret, M.; Colandini, V. Effects of a porous pavement with reservoir structure on runoff water: Water quality and fate of heavy metals. Water Sci. Technol. 1999, 39, 111-117. [CrossRef]

20. Brattebo, B.O.; Booth, D.B. Long-term stormwater quantity and quality performance of permeable pavement systems. Water Res. 2003, 37, 4369-4376. [CrossRef]

21. Myers, B.; Beecham, S.; van Leeuwen, J.A. Water quality with storage in permeable pavement base course. Proc. Inst. Civ. Eng. Water Manag. 2011, 164, 361-372. [CrossRef]

22. Beecham, S.; Pezzaniti, D.; Kandasamy, J. Stormwater treatment using permeable pavements. Proc. Inst. Civ. Eng. Water Manag. 2012, 165, 161-170. [CrossRef]

23. Roseen, R.M.; Ballestero, T.P.; Houle, J.J.; Briggs, J.F.; Houle, K.M. Water Quality and Hydrologic Performance of a Porous Asphalt Pavement as a Storm-Water Treatment Strategy in a Cold Climate. J. Environ. Eng. 2012, 138, 81-89. [CrossRef]

24. Barrett, M. Water quality associated with permeable interlocking concrete pavers. In World Environmental and Water Resources Congress 2015: Floods, Droughts, and Ecosystems_-Proceedings of the 2015 World Environmental and Water Resources Congress; American Society of Civil Engineers (ASCE): Austin, TX, USA, 2015; pp. 453-463. [CrossRef]

25. Abdollahian, S.; Kazemi, H.; Rockaway, T.; Gullapalli, V. Stormwater quality benefits of permeable pavement systems with deep aggregate layers. Environments 2018, 5, 68. [CrossRef]

26. Selbig, W.R.; Buer, N.; Danz, M.E. Stormwater-quality performance of lined permeable pavement systems. J. Environ. Manag. 2019, 251, 109510. [CrossRef] [PubMed]

27. Liu, J.; Yan, H.; Liao, Z.; Zhang, K.; Schmidt, A.R.; Tao, T. Laboratory analysis on the surface runoff pollution reduction performance of permeable pavements. Sci. Total Environ. 2019, 691,1-8. [CrossRef]

28. Pratt, C.J.; Newman, A.P.; Bond, P.C. Mineral oil big-degradation within a permeable pavement: Long term observations. Water Sci. Technol. 1999, 39, 103-109. [CrossRef] 
29. Selvakumar, A.; O'Connor, T.P. Organism Detection in Permeable Pavement Parking Lot Infiltrates at the Edison Environmental Center, New Jersey. Water Environ. Res. 2017, 90, 21-29. [CrossRef] [PubMed]

30. Mahmoud, A.; Alam, T.; Sanchez, A.; Guerrero, J.; Oraby, T.; Ibrahim, E.; Jones, K.D. Stormwater Runoff Quality and Quantity from Permeable and Traditional Pavements in Semiarid South Texas. J. Environ. Eng. 2020, 146, 05020001. [CrossRef]

31. Tota-Maharaj, K.; Scholz, M. Efficiency of permeable pavement systems for the removal of urban runoff pollutants under varying environmental conditions. Environ. Prog. Sustain. Energy 2010, 29, 358-369. [CrossRef]

32. Brown, R.A.; Borst, M. Nutrient infiltrate concentrations from three permeable pavement types. J. Environ. Manag. 2015, 164, 74-85. [CrossRef] [PubMed]

33. Li, H.; Li, Z.; Zhang, X.; Li, Z.; Liu, D.; Li, T.; Zhang, Z. The effect of different surface materials on runoff quality in permeable pavement systems. Environ. Sci. Pollut. Res. 2017, 24, 21103-21110. [CrossRef]

34. Braswell, A.S.; Anderson, A.R.; Hunt, W.F. Hydrologic and water quality evaluation of a permeable pavement and biofiltration device in series. Water 2018, 10, 33. [CrossRef]

35. Razzaghmanesh, M.; Borst, M. Long-term effects of three types of permeable pavements on nutrient infiltrate concentrations. Sci. Total Environ. 2019, 670, 893-901. [CrossRef] [PubMed]

36. Kazemi, F.; Hill, K. Effect of permeable pavement basecourse aggregates on stormwater quality for irrigation reuse. Ecol. Eng. 2015, 77, 189-195. [CrossRef]

37. Paula Junior, A.C.; Jacinto, C.; Oliveira, T.M.; Polisseni, A.E.; Brum, F.M.; Teixeira, E.R.; Mateus, R. Characterisation and life cycle assessment of pervious concrete with recycled concrete aggregates. Crystals 2021, 11, 209. [CrossRef]

38. Wang, Y.; Li, H.; Abdelhady, A.; Li, H.; Harvey, J. Initial evaluation methodology and case studies for life cycle impact of permeability of permeable pavements. Int. J. Transp. Sci. Technol. 2018, 7, 169-178. [CrossRef]

39. Liu, J.; Li, H.; Wang, Y.; Zhang, H. Integrated life cycle assessment of permeable pavement: Model development and case study. Transp. Res. Part D Transp. Environ. 2020, 85, 102381. [CrossRef]

40. Fathollahi, A.; Coupe, S.J. Life cycle assessment (LCA) and life cycle costing (LCC) of road drainage systems for sustainability evaluation: Quantifying the contribution of different life cycle phases. Sci. Total Environ. 2021, 776, 145937. [CrossRef]

41. Singh, A.; Vaddy, P.; Biligiri, K.P. Quantification of embodied energy and carbon footprint of pervious concrete pavements through a methodical lifecycle assessment framework. Resour. Conserv. Recycl. 2020, 161, 104953. [CrossRef]

42. Li, Y.; Huang, J.J.; Hu, M.; Yang, H.; Tanaka, K. Design of low impact development in the urban context considering hydrological performance and life-cycle cost. J. Flood Risk Manag. 2020, 13, e12625. [CrossRef]

43. Rehan, T.; Qi, Y.; Werner, A. Life-cycle cost analysis for traditional and permeable pavements. In Construction Research Congress 2018: Sustainable Design and Construction and Education-Selected Papers from the Construction Research Congress; American Society of Civil Engineers (ASCE): New Orleans, LA, USA, 2018; pp. 422-431. [CrossRef]

44. Antunes, L.N.; Ghisi, E.; Thives, L.P. Permeable pavements life cycle assessment: A literature review. Water 2018, $10,1575$. [CrossRef]

45. Antunes, L.; Thives, L.; Ghisi, E. Potential for Potable Water Savings in Buildings by Using Stormwater Harvested from Porous Pavements. Water 2016, 8, 110. [CrossRef]

46. Antunes, L.N.; Ghisi, E.; Severis, R.M. Environmental assessment of a permeable pavement system used to harvest stormwater for non-potable water uses in a building. Sci. Total Environ. 2020, 746, 141087. [CrossRef]

47. Antunes, L.N.; Sydney, C.; Ghisi, E.; Phoenix, V.R.; Thives, L.P.; White, C.; Garcia, E.S.H. Reduction of environmental impacts due to using permeable pavements to harvest stormwater. Water 2020, 12, 2840. [CrossRef]

48. Garcia, E.S.; Thives, L.P.; Ghisi, E.; Antunes, L.N. Analysis of permeability reduction in drainage asphalt mixtures due to decrease in void volume. J. Clean. Prod. 2020, 248, 119292. [CrossRef]

49. Ghisi, E.; Belotto, T.; Thives, L.P. The use of permeable interlocking concrete pavement to filter stormwater for non-potable uses in buildings. Water 2020, 12, 2045. [CrossRef]

50. Hammes, G.; Thives, L.P.; Ghisi, E. Application of stormwater collected from porous asphalt pavements for non-potable uses in buildings. J. Environ. Manag. 2018, 222, 338-347. [CrossRef]

51. Martins Vaz, I.C.; Ghisi, E.; Thives, L.P. Life cycle energy assessment and economic feasibility of stormwater harvested from pervious pavements. Water Res. 2020, 170, 115322. [CrossRef]

52. Martins Vaz, I.C.; Ghisi, E.; Thives, L.P. Stormwater Harvested from Permeable Pavements as a Means to Save Potable Water in Buildings. Water 2021, 13, 1896. [CrossRef]

53. Thives, L.P.; Ghisi, E.; Brecht, D.G.; Pires, D.M. Filtering capability of porous asphalt pavements. Water 2018, 10, 206. [CrossRef]

54. Thives, L.P.; Ghisi, E.; da Silva, N.M. Potable Water Savings in Multifamily Buildings Using Stormwater Runoff from Impermeable Paved Streets. Eur. J. Sustain. Dev. 2018, 7, 120-130. [CrossRef]

55. Associação Brasileira De Normas Técnicas (ABNT). NBR 13969: Septic Tank-Units for Treatment and Disposal of Liquid EffluentsProject, Construction and Operation; ABNT: Rio de Janeiro, Brazil, 1997.

56. Ghisi, E.; Cordova, M.M. Netuno 4 Programme (Netuno 4, Programa Computacional); LABEEE: Florianópolis, Brazil, 2014. (In Portuguese)

57. Guimarães, J.M.F. Porous Asphalt Mixtures Modified with SBS Polymer and Tyre Rubber (Concreto Asfáltico Drenante em Asfaltos Modificados por Polímero SBS e Borracha moíDa de Pneus). Master's Thesis, Universidade Federal de Santa Catarina, Florianópolis, Brazil, 2012. (In Portuguese) 
58. DNIT. DNER-ES 386/99_Porous Friction Layer with Polymer Asphalt; Departamento de Infraestrutura Rodoviária, Norma Rodoviária: Rio de Janeiro, Brazil, 1999.

59. ASTM. Annual Book of ASTM Standards; American Society for Testing and Materials: West Conshohocken, PA, USA, 2002.

60. AFNOR. NF P 98-250-2: Essais Relatifs Aux Chaussées, Preparation des Mélanges Hydrocarbonés, Partie 2: Compactage des Plaques; Association Francaise de Normalisation: Paris, France, 1991. (In French)

61. AASHTO. R35-Standard Practice for Superpave Volumetric Design for Asphalt Mixtures; American Association of State Highway and Transportation Officials: Washington, DC, USA, 2015.

62. AFNOR. NF P98-254-2: Mesure de Proprietés Liées à la Perméabilité des Matériaux des Mélanges Hydrocarbonés, Partie 2; Association Francaise de Normalisation: Paris, France, 1993. (In French)

63. (CEDEX): Gabinete de Formación y Documentación; Centro de Estudios y Experimentación de Obras Públicas. NLT-327/00. Permeabilidad in Situ de Pavimentos Drenantes Con el Permeámetro LCS; Centro de Estudios y Experimentación de Obras Públicas: Madrid, Spain, 1996.

64. DNER (Departamento Nacional de Estradas de Rodagem). DNER-ME 081: Agregados—Determinação da Absorção e da Densidade de Agregado Graúdo; DNER: Rio de Janeiro, Bazil, 1998; Volume 81, pp. 1-6.

65. DNER (Departamento Nacional de Estradas de Rodagem). ME 084/95—Agregado miúdo—Determinação da Densidade Real; DNER: São Paulo, Brazil, 1995.

66. Caltrans. Method of Test for Optimum Bitumen Content (OBC) for Open Graded Friction Course-California Test 368; Caltrans: San Francisco, CA, USA, 2010.

67. PMSP (Prefeitura do Município de São Paulo). ESP-10/92 Camadas de Pré-Misturado a Quente; PMSP: São Paulo, Brazil, 1992. (In Portuguese)

68. Associação Brasileira De Normas Técnicas (ABNT). NBR 9781—Concrete Paving Units—Specification and Test Methods; ABNT: Rio de Janeiro, Brazil, 2013.

69. ANA. Water Conservation and Reuse in Buildings. Agência Nacional de Águas; Editora Gráfica: São Paulo, Brazil, 2005. (In Portuguese)

70. Associação Brasileira De Normas Técnicas (ABNT). NBR 16783: Use of Alternative Sources of Non-Potable Water in Buildings; ABNT: Rio de Janeiro, Brazil, 2019.

71. Associação Brasileira De Normas Técnicas (ABNT). NBR 15527: Rainwater Harvesting from Roofs for Non-Potables Uses—Requirements (Água de Chuva-Aproveitamento de Coberturas em áreas Urbanas para Fins não Potáveis—Requisitos); ABNT: Rio de Janeiro, Brazil, 2007. (In Portuguese)

72. Conselho Nacional do Meio Ambiente. Conselho Nacional do Meio Ambiente Resolução No 357, de 18 de Março de 2005. Classificação dos Corpos de Água e Diretrizes Ambientais Para Seu Enquadramento; Ministério Nacional do Meio Ambiente: Brasília, Brazil, 2005. (In Portuguese)

73. Conselho Nacional do Meio Ambiente. Conselho Nacional do Meio Ambiente Resolução No 430, de 13 de Maio de 2011. Condições e Padrões de Lançamento de Efluentes; Ministério Nacional do Meio Ambiente: Brasília, Brazil, 2011. (In Portuguese)

74. Drake, J.A.; Bradford, A.; Marsalek, J. Review of environmental performance of permeable pavement systems: State of the knowledge. Water Qual. Res. J. Can. 2013, 48, 203-222. [CrossRef]

75. Scholz, M.; Grabowiecki, P. Review of permeable pavement systems. Build. Environ. 2007, 42, 3830-3836. doi:10.1016/j.buildenv.2006.11.016. [CrossRef]

76. Tota-Maharaj, K.; Coleman, N. Developing novel photocatalytic cementitious permeable pavements for depollution of contaminants and impurities in urban cities. In Proceedings of the 10th International Conference on Environmental Engineering, Shenzhen, China, 27-28 April 2017; pp. 27-28. [CrossRef]

77. Zhao, L.; Chen, R.; Pang, L.X.; Zhang, W.; Tan, X. Study on Photo-catalytic Efficiency and Durability of Nano-TiO2 in Permeable Concrete Pavement Structure. IOP Conf. Ser. Earth Environ. Sci. 2019, 371, 042011. [CrossRef]

78. Rocha, V. Netuno's Algorithm Validation to Evaluate the Potential for Potable Water Savings and Sizing of Rainwater Reservoirs in Buildings (Validação do Algoritmo do Programa Netuno para Avaliação do Potencial de Economia de água Potável e Dimensionamento de Reservatórios de Aproveitamento de água Pluvial em Edificações. Ph.D. Thesis, Universidade Federal de Santa Catarina, Santa Catarina, Brazil, 2009. (In Portuguese)

79. Acioli, L.A. Experimental Study of Permeable Pavements for the Control of Surface Runoff at the Source (Estudo Experimental de Pavimentos Permeaveis para o Controle do Escoamento Superficial na Fonte). Master's Thesis, Universidade Federal do Rio Grande do Sul, Rio Grande do Sul, Brazil, 2005. (In Portuguese)

80. Pinto, L. Performance of Permeable Pavements as a Mitigating Measure for Urban Soil Sealing (Desempenho de Pavimentos Perme aveis como Medida Mitigadora da Impermeabilizaçao do Solo Urbano). Ph.D. Thesis, Escola Politécnica, Universidade de São Paulo, São Paulo, Brazil, 2011. (In Portuguese)

81. CIRIA. The Sustainable Drainage Systems (SUDS) Manual. Construction Industry Research and Information Association (CIRIA), u.k978-086 ed.; CIRIA: London, UK, 2015.

82. Silveira, A.L.L.D. Hydrologic Pre-Sizing of Permeable Pavements and Infiltration Trenches (Pré-Dimensionamento Hidrológico de Pavimentos Permeáveis e Trincheiras de Infiltração). In Simpósio Brasileiro de Recursos Hídricos, XV; ABRH: Curitiba, Brazil, 2003. (In Portuguese)

83. Associação Brasileira De Normas Técnicas (ABNT). NBR 16416: Pervious Concrete Pavement_-Requirements and Procedures; ABNT: Rio de Janeiro, Brazil, 2015. 
84. Huijbregts, M.A.; Steinmann, Z.J.; Elshout, P.M.; Stam, G.; Verones, F.; Vieira, M.; Zijp, M.; Hollander, A.; van Zelm, R. ReCiPe2016: A harmonised life cycle impact assessment method at midpoint and endpoint level. Int. J. Life Cycle Assess. 2017, 22, 138-147. [CrossRef]

85. Goedkoop, M.; Heijungs, R.; Huijbregts, M.; Schryver, A.D.; Struijs, J.; Zelm, R.V. ReCiPe 2008; Ministerie van Volkshuisvesting, Ruimtelijke Ordening en Milieubeheer: Wageningen, The Netherlands, 2009; pp. 1-126. 